Original Research Paper

\title{
The Role of the Principal in Improving Teacher Performance in the Development of Evaluation of Learning Outcomes through Academic Supervision of Principals during the Covid-19 Pandemic
}

\author{
Suprapti ${ }^{*}$ \\ ${ }^{1}$ Senior High School 8 Mataram, Mataram, Indonesia.
}

*Corresponding Author: Suprapti, Senior High

School 8 Mataram,

Indonesia

Email:

suprapti.orbit@gmail.com

\begin{abstract}
Abstrak: The ability of teachers at SMA Negeri 8 Mataram is still very concerning, especially when evaluating learning outcomes. This is becoming increasingly worrying with the current condition, namely the Covid-19 Pandemic where all learning processes must be conducted online. The aim of this study was to determine whether the role of the principal through online academic supervision can improve teacher performance in evaluating learning outcomes at SMA Negeri 8 Mataram. This research is included in the School Action Research. At school, action research is conducted in 2 cycles. The results showed that in cycle I the percentage of teacher completeness was $28.12 \%$ and in cycle II the percentage of teacher achievement was $89.06 \%$. The results of this study clearly indicate that the principal plays an important role in conducting academic supervision of teachers, especially in developing the evaluation of student learning outcomes. Therefore, it is concluded that coaching through the academic supervision of the principal can improve the performance of SMA Negeri 8 Mataram teachers in developing evaluation of learning outcomes with a completeness of greater than or equal to $85 \%$.
\end{abstract}

Keywords: Academic Supervision; Evaluation of Learning Outcomes; Teacher Performance.

\section{Pendahuluan}

The COVID-19 pandemic is a disaster that has befallen society worldwide (Supriatna, 2020). All segments of human life on Earth are disrupted, including the education part (Aji, 2020). Several countries have even decided to close schools, colleges and universities, including our country, namely Indonesia (Sourial et al., 2020). The Indonesian government had to take a bitter decision because they had to close schools to reduce the contact of people flock.

The most prominent impact on education sustainability caused by the Covid19 pandemic is that the government requires students to go from home to school (Mastura \& Santaria, 2020). As a result, the learning process must take place online (online). This is definitely something new for both teachers and students.

This online learning clearly has an impact on the learning process, especially the learning outcome evaluation process performed by the teacher (Putria et al., 2020). This condition is exacerbated by the lack of an optimal supervision function of the client. The principal has difficulty following the teacher's learning process and it is difficult to know how the teacher's learning evaluation process is being conducted during this pandemic period. So that the director needs another 
breakthrough to improve teacher performance, especially when evaluating students' learning outcomes.

Based on the results of monitoring by the director of SMA Negeri 8 Mataram, so far, the ability of teachers to be concerned, especially when evaluating learning outcomes. In combination with the current circumstances.

This research was conducted with the aim of understanding the role of school principals in improving teacher performance in developing the evaluation of learning outcomes during the Covid-19 pandemic.

\section{Method}

This research is a School Action Research (PTS). Action research includes planning actions based on the problems faced, implementing actions, observing and collecting data, analyzing research data, reflecting on the results of the analysis, changing/revising plans for further development (Slameto, 2015). This study consisted of 2 cycles, namely cycle I and cycle II. The subjects in this study were teachers of SMA Negeri 8 Mataram in the 2019/2020 academic year. This type of research is school action research through the application of academic supervision of the Principal which is carried out online using the ZOOM form and the research instruments are sent via Google Form. The number of teachers who were the objects of this study were 64 teachers. The criteria used in measuring teacher performance is the percentage of completeness above $85 \%$ with the criterion of completeness processing a score of $\geq 75$.

\section{Hasil dan Pembahasan}

\section{Cycle I}

\section{a) Planning Stage}

At this stage the researcher prepares a coaching tool consisting of a coaching plan, instruments, and other supporting devices.

b) Activity and Implementation Stage

The implementation of coaching activities for cycle I was carried out on March 16, 2020 using the Zoom Platform. In this case the researcher acts as the principal. The coaching process refers to the coaching plan that has been prepared. At the end of the coaching process, the teacher was given an instrument to fill in to find out the performance of SMA Negeri 8 Mataram teachers during the Covid-19 pandemic. The research data in the first cycle are given as in Table 1.

Table 1: Score Distribution Table in Cycle I

\begin{tabular}{llll}
\hline Respondents & Score & \multicolumn{2}{l}{ Information } \\
\hline Teacher 1 & 70 & & Not complete \\
Teacher 2 & 75 & Complete & \\
Teacher 3 & 60 & & Not complete \\
Teacher 4 & 50 & & Not complete \\
Teacher 5 & 80 & Complete & \\
Teacher 6 & 50 & & Not complete \\
Teacher 7 & 60 & & Not complete \\
Teacher 8 & 85 & Complete & \\
Teacher 9 & 65 & & Not complete \\
Teacher 10 & 50 & & Not complete \\
Teacher 11 & 80 & Complete & \\
Teacher 12 & 55 & & Not complete \\
Teacher 13 & 60 & & Not complete \\
Teacher 14 & 50 & & Not complete \\
Teacher 15 & 80 & Complete & \\
Teacher 16 & 55 & & Not complete \\
Teacher 17 & 60 & & Not complete \\
Teacher 18 & 65 & & Not complete \\
Teacher 19 & 65 & & Not complete \\
Teacher 20 & 80 & Complete & \\
Teacher 21 & 70 & & Not complete \\
Teacher 22 & 60 & & Not complete \\
Teacher 23 & 60 & & Not complete \\
Teacher 24 & 75 & & Not complete \\
Teacher 25 & 50 & & Not complete \\
Teacher 26 & 65 & & Not complete \\
Teacher 27 & 80 & Complete & \\
Teacher 28 & 50 & & Not complete \\
Teacher 29 & 65 & & Not complete \\
Teacher 30 & 50 & & Not complete \\
Teacher 31 & 80 & Complete & \\
Teacher 32 & 80 & Complete & \\
Teacher 33 & 60 & & Not complete \\
Teacher 34 & 65 & & Not complete \\
Teacher 35 & 70 & & Not complete \\
Teacher 36 & 60 & & Not complete \\
Teacher 37 & 60 & & Not complete \\
Teacher 38 & 50 & & Not complete \\
Teacher 39 & 75 & Complete & \\
\hline & & & \\
\hline
\end{tabular}




\begin{tabular}{llll}
\hline Respondents & Score & \multicolumn{2}{l}{ Information } \\
\hline Teacher 40 & 50 & & Not complete \\
Teacher 41 & 60 & & Not complete \\
Teacher 42 & 80 & Complete & \\
Teacher 43 & 65 & & Not complete \\
Teacher 44 & 50 & & Not complete \\
Teacher 45 & 80 & & Not complete \\
Teacher 46 & 55 & & Not complete \\
Teacher 47 & 75 & Complete & \\
Teacher 48 & 65 & & Not complete \\
Teacher 49 & 50 & & Not complete \\
Teacher 50 & 80 & & Not complete \\
Teacher 51 & 70 & & Not complete \\
Teacher 52 & 60 & & Not complete \\
Teacher 53 & 80 & Complete & \\
Teacher 54 & 50 & & Not complete \\
Teacher 55 & 50 & & Not complete \\
Teacher 56 & 75 & Complete & \\
Teacher 57 & 60 & & Not complete \\
Teacher 58 & 50 & & Not complete \\
Teacher 59 & 80 & Complete & \\
Teacher 60 & 75 & Complete & \\
Teacher 61 & 60 & & Not complete \\
Teacher 62 & 75 & Complete & \\
Teacher 63 & 65 & & Not complete \\
Teacher 64 & 75 & Complete & \\
Total & & 18 & 46 \\
Percentage & & 28,12\% & 72,88\% \\
\hline & & &
\end{tabular}

From table 1 it can be explained that with the guidance carried out by the Principal through online academic supervision, it was found that $18(28.12 \%)$ teachers out of 64 teachers had completed. These results indicate that in the first cycle the teacher's performance has not improved, because those who get a value of $\geq 75$ are only $28.12 \%$ and smaller than the desired percentage of completeness, which is $85 \%$. This is because the teachers of SMA Negeri 8 Mataram are still not used to learning and being supervised by the online system due to the Covid-19 pandemic as it is today.

\section{c) Reflection}

In the implementation of coaching activities carried out online, information is obtained from the observation that the principal must carry out coaching more regularly and be carried out online in conducting coaching at schools. The principal must also use more time in conducting online coaching and the principal must concentrate more on coaching, because apart from coaching, there are other tasks that must be done.

\section{d) Design Revision}

There are still shortcomings in the implementation of coaching activities in the first cycle, so there needs to be a revision to be made in the next cycle. The thing that needs to be considered is that the principal needs to be more skilled in motivating teachers and more clearly in conveying the objectives of coaching carried out online. The principal also needs to distribute time properly by adding information that is deemed necessary and providing notes, and must be more skilled and enthusiastic in motivating teachers so that their performance is more improved.

\section{Cycle II}

a) The planning stage

At this stage the researcher prepares a coaching tool consisting of coaching plan 2, research instruments, and other necessary tools.

b) Activity and implementation stage

The implementation of managerial supervision coaching activities for cycle II was carried out on June 20, 2020. In this case the researcher acts as the principal of the school. The coaching process refers to the coaching plan by taking into account the revisions in cycle $\mathrm{I}$, so that mistakes or deficiencies in cycle I do not happen again in cycle II. This school action research is carried out in accordance with the guidance plan procedures and guidance scenarios during the teaching and learning process.

At the end of the teacher coaching process, research instruments were distributed again through Google Form with the aim of determining the level of success in improving performance. The research data in the second cycle are presented in table 2 . 
Table 2. Score Distribution Table in Cycle II

\begin{tabular}{|c|c|c|c|}
\hline Respondents & Score & Information & \\
\hline Teacher 1 & 75 & Complete & \\
\hline Teacher 2 & 85 & Complete & \\
\hline Teacher 3 & 75 & Complete & \\
\hline Teacher 4 & 75 & Complete & \\
\hline Teacher 5 & 85 & Complete & \\
\hline Teacher 6 & 75 & Complete & \\
\hline Teacher 7 & 80 & Complete & \\
\hline Teacher 8 & 90 & Complete & \\
\hline Teacher 9 & 80 & Complete & \\
\hline Teacher 10 & 75 & Complete & \\
\hline Teacher 11 & 95 & Complete & \\
\hline Teacher 12 & 75 & Complete & \\
\hline Teacher 13 & 75 & Complete & \\
\hline Teacher 14 & 65 & & Not complete \\
\hline Teacher 15 & 95 & Complete & \\
\hline Teacher 16 & 75 & Complete & \\
\hline Teacher 17 & 80 & Complete & \\
\hline Teacher 18 & 80 & Complete & \\
\hline Teacher 19 & 85 & Complete & \\
\hline Teacher 20 & 80 & Complete & \\
\hline Teacher 21 & 85 & Complete & \\
\hline Teacher 22 & 75 & Complete & \\
\hline Teacher 23 & 75 & Complete & \\
\hline Teacher 24 & 80 & Complete & \\
\hline Teacher 25 & 65 & & Not complete \\
\hline Teacher 26 & 80 & Complete & \\
\hline Teacher 27 & 95 & Complete & \\
\hline Teacher 28 & 75 & Complete & \\
\hline Teacher 29 & 80 & Complete & \\
\hline Teacher 30 & 75 & Complete & \\
\hline Teacher 31 & 95 & Complete & \\
\hline Teacher 32 & 95 & Complete & \\
\hline Teacher 33 & 80 & Complete & \\
\hline Teacher 34 & 85 & Complete & \\
\hline Teacher 35 & 80 & Complete & \\
\hline Teacher 36 & 80 & Complete & \\
\hline Teacher 37 & 75 & Complete & \\
\hline Teacher 38 & 65 & & Not complete \\
\hline Teacher 39 & 85 & Complete & \\
\hline Teacher 40 & 55 & & Not complete \\
\hline Teacher 41 & 80 & Complete & \\
\hline Teacher 42 & 85 & Complete & \\
\hline Teacher 43 & 75 & Complete & \\
\hline Teacher 44 & 75 & Complete & \\
\hline Teacher 45 & 80 & Complete & \\
\hline Teacher 46 & 65 & & Not complete \\
\hline Teacher 47 & 90 & Complete & \\
\hline Teacher 48 & 85 & Complete & \\
\hline Teacher 49 & 75 & Complete & \\
\hline Teacher 50 & 85 & Complete & \\
\hline Teacher 51 & 90 & Complete & \\
\hline
\end{tabular}

\begin{tabular}{|c|c|c|c|}
\hline Teacher 52 & 85 & Complete & \\
\hline Teacher 53 & 90 & Complete & \\
\hline Teacher 54 & 65 & & Not complete \\
\hline Teacher 55 & 65 & & Not complete \\
\hline Teacher 56 & 85 & Complete & \\
\hline Teacher 57 & 75 & Complete & \\
\hline Teacher 58 & 75 & Complete & \\
\hline Teacher 59 & 85 & Complete & \\
\hline Teacher 60 & 85 & Complete & \\
\hline Teacher 61 & 75 & Complete & \\
\hline Teacher 62 & 90 & Complete & \\
\hline Teacher 63 & 75 & Complete & \\
\hline Teacher 64 & 85 & Complete & \\
\hline Total & & 57 & 7 \\
\hline Percentage & & $89,06 \%$ & $10,94 \%$ \\
\hline
\end{tabular}

From table 2, the percentage value of teacher performance is $89.06 \%$ complete and $10.94 \%$ unfinished. These results indicate that in cycle II the increase in teachers has increased from cycle I. There is an increase in teacher performance because after the Principal has informed that at the end of each coaching there will be an assessment so that at the next meeting the teacher is more motivated to improve their performance. In addition, teachers have also begun to understand what the principal means and wants in conducting academic supervision of the principal.

\section{c) Reflection}

At this stage, what has been done well and what is still not good will be examined in the coaching process through online academic supervision. From the data that has been obtained, it can be described as follows:

(1) During the online process of coaching Principals, all coaching has been carried out properly. Although there are some imperfect aspects, the percentage of implementation for each aspect is quite large.

(2) Based on the observation data, it is known that the teacher is active during the coaching process even though it is done online.

(3) The deficiencies in cycle I have experienced improvements and 
improvements so that they are better.

(4) The results of the principal's coaching by the school principal through academic supervision in cycle II reach completeness.

\section{d) Implementation Revision}

In cycle II, even though it was carried out online, the principal had carried out coaching well and seen from the improvement in teacher performance, the implementation of coaching had gone well. So there is no need for too many revisions, but what needs to be considered for further action is to maximize and maintain what already exists with the aim that in the implementation of further coaching through academic supervision it can improve teacher performance so that the objectives of coaching as an effort to improve the quality of education can be achieved.

This classroom action research was conducted by the principal in 2 (two) cycles, namely Cycle I and Cycle II. This research was conducted online because of the conditions we are currently facing, namely the Covid 19 pandemic. This requires that the implementation of learning carried out by teachers must be done online. This online learning activity is something new for all teachers including teachers at SMA Negeri 8 Mataram. Thus, the principal who is currently a researcher feels it is very necessary to supervise online guidance as well as to motivate teachers so that teacher performance continues to increase as expected.

The implementation of supervision in Cycle I resulted in unsatisfactory teacher performance. The results of the data analysis showed that only $28.12 \%$ of the teachers had completed or were considered to have good performance while learning was carried out online. This is certainly a big concern for researchers as the principal.

Seeing the results in cycle I, the researcher returned to supervision in Cycle II by correcting several deficiencies in Silklus I, and finally in cycle II the results showed that $89 \%$ of the teachers had completed or had good performance. This result exceeds the joint completeness criteria of $85 \%$ of teachers. This result is very satisfying because continuous supervision will improve teacher performance both online and online. This is indicated by an increase in teacher performance by $60.94 \%$ from Cycle I to Cycle II.

\section{Conclusion}

Based on the analysis of the results of research and discussion, it can be concluded that 1) Principal coaching in an effort to improve teacher performance through academic supervision of the Principal conducted online shows an increase. 2) Activities in coaching activities show that all teachers can improve their performance well in every aspect even though they are done online. 3) The activities of the principal show that coaching activities through academic supervision of the principal are useful and can help teachers to more easily understand the concept of teacher roles and functions so that teacher performance can increase.

\section{References}

Aji, R. H. S. (2020). Dampak Covid-19 pada Pendidikan di Indonesia: Sekolah, Keterampilan, dan Proses Pembelajaran. SALAM; Jurnal Sosial \& Budaya Syar-I, 7(5). https://doi.org/10.15408/sjsbs.v7i5.1531 4

Mastura, \& Santaria, R. (2020). Dampak Pandemi Covid-19 terhadap Proses Pengajaran bagi Guru dan Siswa Pendahuluan. Jurnal Studi Guru Dan Pembelajaran, 3(2), 289-295.

Putria, H., Maula, L. H., \& Uswatun, D. A. (2020). Analisis Proses pembelajaran Dalam Jaringan (DARING) Masa Pandemi COVID-19 pada Guru Sekolah Dasar. Jurnal Basicedu, 4(4), 861-872. https://doi.org/10.31004/basicedu.v4i4.4 60 
Slameto, S. (2015). Implementasi Penelitian Tindakan Kelas. Scholaria: Jurnal Pendidikan Dan Kebudayaan, 5(3), 47. https://doi.org/10.24246/j.scholaria.2015 .v5.i3.p47-58

Sourial, N., Longo, C., Vedel, I., \& Schuster, T. (2018). Daring to draw causal claims from non-randomized studies of primary care interventions. Family Practice, 35(5), 639643.

https://doi.org/10.1093/fampra/cmy005

Supriatna, E. (2020). Wabah Corona Virus Disease (Covid 19) Dalam Pandangan Islam. SALAM: Jurnal Sosial Dan Budaya Syar-I, https://doi.org/10.15408/sjsbs.v7i6.1524 7 